favour, coupled, by the way, with financial help from the syndics of the University Press.

A few words are due to the Rev. W. Farish, first president of the Cambridge Philosophical Society. Born in 1759, he was educated at Carlisle Grammar School. He graduated in 1778, being senior wrangler and first Smith's prizeman. Farish was instituted Jacksonian professor of natural and experimental philosophy in 1813, succeeding the Rev. F. J. Hyde Wollaston, a brother of William Hyde Wollaston. Earlier (1794) Farish had been chosen professor of chemistry. In 1796 he published a plan of a course of lectures on arts and manufactures in relation to chemistry, a scheme in all likelihood derived in the main from his predecessor, who himself was responsible for "A Plan of a Course of Chemical Lectures". Farish was the author of six papers read before the Society, one of them (1820) under the title "On the Mode of Conducting Polar Navigation".

Space would forbid other than cursory notice of memoirs read in the first half-century of the Society's career. The chief publication began in 1820, entitled Transactions, supplemented in 1843 by Proceedings. They both enjoy a world-wide circulation now. In the spring of 1820 , J. F. W. Herschel communicated three papers, and in 1835 came letters from the Cape of Good Hope detailing meteorological observations made there by him. Similarly, at the same meeting, letters were read from Charles Darwin containing accounts of the geology of certain parts of the Andes and South America. Very much later (In 1860), Darwin is writing thus to Lyell: "I had a letter from Henslow this morning, who says that Sedgwick was ... to open a battery on me at the Cambridge Philosophical Society. Anyhow, I am much honoured by being attacked there, and at the Royal Society of Edinburgh". Faraday had written in 1823 accepting honorary membership. Airy, whilst yet a student at Trinity College, communicated a paper, followed by others, down to 1840 . Whewell provided many papers. But such records are readily capable of indefinite extension, reaching into another half-century, and that is not practicable. Suffice that the names of some of the bestknown exponents of science in almost all departments appear in the lists of past presidents. We learn that to-day, tea before meetings, as in "another place", fortifies those numerous authors whose memoirs have, of necessity, to be "taken as read". The separate publication of Biological Reviews and Biological Proceedings is an undertaking of recent years which has proved of great value.

It is of interest to record that at the annual general meeting in 1895, Prof. J. J. Thomson, president, in the chair, the subjoined resolution was adopted : "That the Fellows of the Cambridge Philosophical Society at this their first meeting since the death of Professor Thomas Henry Huxley desire to express their sympathy with Mrs. Huxley, and to record their sense of the depth of his influence on modern thought, and on the progress of biological science".

In its youthful period, aided by the lively interest of Prof. Henslow, the Society took pains to form collections exemplifying natural history. In process of time this important nucleus of a great museum was given accommodation elsewhere (1865). There has been gradually brought together a reference library of most creditable size, and it includes numerous runs or sets of scientific periodicals. The adequate and safe housing of this library-none too well assured at present-is receiving attention.

The Cambridge Philosophical Society, unlike many other scientific institutions, has no trust funds of its own, and has never had the good fortune to receive a legacy or other special benefaetion.
T. E. JAMES.

\title{
Obituary
}

Sir Dugald Clerk, K.B.e., F.R.s.

$\mathrm{B}^{\mathrm{Y}}$ $Y$ the death of Sir Dugald Clerk on November 12 , following comparatively closely on that of Sir Charles Parsons, Great Britain has lost the two greatest engineers in history, at least in the field of power production.

To the imagination, to the detailed scientific research and still more to the lucid and admirable teaching of these two men, are due the whole moderm system of power production as we see it to-day, on land, on the water, and in the air. Just as Sir Charles Parsons by his development of the turbine revolutionised and revived the use of steam until none but his methods are employed to-day, so Sir Dugald Clerk nursed the internal combustion engine almost from the day of its birth as a sickly infant of little more than medical interest, nursed and reared it, until to-day it has become the greatest factor in modern engineering -indeed one might almost say in modern civilisation. In the early stages of its infancy, when 'doctors' differed and none knew how to feed or tend it, it was Clerk who first explained to the faculty how its delicate interior functioned, how its growth and strength could best be fostered, and where its frailties lay. Since that day, Clerk watched ceaselessly over and reared this child and its offspring through many generations, until to-day it has peopled the earth, the sea, and the sky. Many thousands of 'doctors' in all the countries of the world have since adopted and specialised in the care of this fertile breed, but one and all, consciously or unconsciously, have drawn their inspiration and their methods from the teachings of Sir Dugald Clerk.

We are prone to set great store by invention, and Clerk's inventions in this field were many and important, the best known perhaps being that

No. 3295, VoL. 130] 
of the two-stroke cycle engine; but inventors are plentiful and inventions mark phases only. The great value of Clerk's work lies rather in his brilliant analyses of the working processes, in his lucid presentations of these in a form which appeal alike to the student, to the purely scientific investigator, and to the practical engineer-these will live for ever.

In his earlier work Clerk could rely for his observations only on the very imperfect and erratic instruments which were available, but he sifted and supplemented these often conflicting observations with such judgment and insight, and with such a breadth of imagination, that all his deductions have stood the test of time and hold good to-day.

The value of Clerk's scientific work was enhanced greatly by the extraordinary charm of his personality, by his kindliness and encouragement and by the almost limitless trouble he took to assist and encourage all the younger generation. My first meeting with Sir Dugald Clerk was some twenty-five years ago. As a very young man I had invented, or thought I had invented, an improved type of engine; I had submitted this invention to a manufacturing firm, who had referred it to Sir Dugald Clerk. Sir Dugald sent for me and explained that, reluctantly, he had turned down my invention; he explained exactly why and urged me not to be discouraged-he suggested many ways in which the idea could be improved, and invited me to call on him at any time for any help or advice he could give. At once I fell a victim to his charm and the obvious sincerity of his kindness-a kindness which he bestowed on me from that time until the day of his death.

Too often one has to record the great work of a man left unrecognised and unappreciated until after his death. Fortunately this does not apply in Sir Dugald Clerk's case : his work was known and recognised all the world over and he was honoured, as was his due, by the leading scientificinstitutions of his day and by hisinnumerable friends and admirers. His scientific lectures were always a joy to attend, not alone for the value of the material they contained, but also for the sheer joy of listening to his beautiful diction and his pleasant voice.

H. R. RiCARDo.

\section{Mr. T. G. Sloane}

Thomas Gibson Sloane, of Moorilla Station, Young, New South Wales, who died on October 20, combined the unusual association of sheep-breeder, philosopher, naturalist in general and entomologist in particular. One of five sons of Alexander Sloane, of Mulwala, Murray River, a well-known merino expert, he was educated partly at the Scot's College, Melbourne, partly by tutor at home. There was a strong literary taste in the family, and a fine knowledge of the English poets was a background of his well-stored mind. He was sent to Sydney to learn business methods and returned to manage Moorilla for the firm of Alexander Sloane and Sons, which he inherited as his life-long home. Here he won numerous prizes for sheep at various shows; had a stud of his own registered in the flock book; kept accurate records of wool weights and was a regular attendant at Sydney sheep sales.

In Sydney, however, Sloane also met Sir W. Macleay and his sclentific henchman, the late J. J. Fletcher, who became his lifelong friend; and in 1888 contributed his first paper on Carabidæ to the Linnean Society of New South Wales. Natural history was his passion, and I have never met any man who so closely and enthusiastically studied Darwin, especially "The Origin of Species".

As an entomologist Sloane was soon recognised as the Australian authority on the Carabidæ, though he later included the Cicendelidæ in his studies. But his mental horizon was too wide to allow himself to be limited to collecting and describing new species. Phylogeny and distribution greatly occupied him. His paper on the "Faunal Subregions of Australia" has often been quoted by later authors, while his "Classification of the Family Carabide" (Trans. Ent. Soc. London, 1923) has received wide notice. Sloane's "Table of Tribes" has been adopted as being the most satisfactory classification in existence.

Sloane contributed some sixty-one papers to various societies-the great majority to the Linnean Society of New South Wales-and described 595 new species, of which 557 were Carabidæ, including a few from New Guinea. With a world-wide correspondence, he found time to help his brother entomologists generously by naming their collections, until later years brought those economic worries that have especially troubled Australian pastoralists.

I accompanied him on many a distant trip through Queensland, Western Australia, New South Wales and Victoria. He was a delightful companion and a lovable friend, with an unlimited stock of yarns, and a good 'mixer' with bush folk, whom he understood. A retentive, but not a wide, reader, he avoided modern fiction, but collected a good library especially on Australian exploration and traveller naturalists. Generous in excess to others, sparing in his own needs, a stoic by nature and will, his last years were spent in hard work on his homestead. He passed away at the Burrangong Hospital, Young, a victim to cardiac asthma, leaving a widow, two sons and four daughters to mourn his loss. H. J. CARTER.

Mr. G. B. Scotr, o.I.E.

By the death of Mr. G. B. Scott, which took place at Bournemouth on November 20 at the age of eighty-eight years, a distinguished Indian frontier surveyor passed away.

Scott's memory carried him as far back as the stirring times of the Second Sikh War. He was educated at the Lawrence Military Asylum at

No. 3295, Vol. 130] 